\title{
新しい霊長類学, 霊長類医科学試論
}

\author{
野口淳 夫
}

筑波大学基礎医学系

\section{1. はじめに}

医学やその関連領域において霊長類にかかわっ てきた研究者が日本霊長類学会に必ずしも結集せ ず，その研究成果屯学会に十分には反映されて来 なかったことは, 霊長類学の発展にとって大きな 損失であると思う。このことは，学会の中で実験 系之呼ばれている研究者たちの一部のあいだでだ いぶ前から論議されていた。そのような状況を招 いたひとつの原因として，日本における霊長類の 学問・研究が生態学を中心とした野生のサルの研 究から始まり, 実験系の研究や学問が遅れて出発 したことにあることを挙げることができるのでは ないか。また, 生態系の研究が日本の霊長類学と しての特徴をそなえて発展してきたことに比して, 実験系の研究はその多くが個別の学問分野の中で, 実験材料としてサルを使うことによって生まれ， その後む基本的にその流れの中で展開されてきた ため, 生態系の研究のように霊長類を軸とした学 問としてのまとまりや特徴づけがなされてこなかっ たことも一因かもしれない。

一般に, 霊長類を用いて実験的研究をしている からと言って, その研究者が霊長類学として位置 づけられるような研究をしていると自覚している とは限らない。というより, 医学やその関連分野 で霊長類を使って研究や試験をしている者の大部 分は, そのような意識をほとんど持っていないの ではなかろうか。例外的に, 主に実験動物学の流 れの中で霊長類 (非ヒト霊長類) の研究を行って
きた研究者たちがこの学会に結集したが，そのよ うな研究者たちは霊長類を自らの学問の中心に据 えるという意識においては, 生態系の研究者たち と全く変らないものを持っていたのは確かである。 その結果, 霊長類学会に結集してくる実験系の研 究者の枠組みが相当偏ったものとなった印象を与 え, 幅広く研究者たちを結びっけ得なかったこと あ事実であろう。このような閉塞した状況を改善 し，より広いすそ野を持った実験系の研究者を結 集できれば, 霊長類学の発展にとっても大いに有 益であると思われる。そうなれば, これまで材料 や方法としてのみ霊長類をとらえ, それぞれ固有 の学問領域の中でのみ交流を行ってきた研究者た ちにとっても, 霊長類を軸とした広い視野からの 研究を進められる可能性が出てくるのではなかろ うか。また，それらの実験や試験に用いられるサ ル類の質や量に関する様々な問題む, 霊長類学の 枠組みに中でこそ適切な対応を取ることもできる と考えられるのである。

\section{2. 新しい総合科学としての霊長類医科学}

実験系の霊長類学の裾野を広げるためには, よ゙ のような手だてを講ずれば良いのであろうか。上 述のような原因として考えられる事柄を分析して 見てあなかなか良い智恵は浮かんでこない。学問 の成り立ちや発展経過には歴史的な経緯があり, それらから自由になることは容易ではないからで ある。ところで実験系の霊長類学の枠組みを広げ 
るという問題は, あう少し深い意味を持つのでは ないか。この問題は霊長類学会に結集する実験系 の研究者の要求として出てきている。すなわち, 霊長類にかかわる実験系の研究者自らの学問の独 自化を欲する内的必要性に基づいている。そのた めには, 実験系の霊長類学の流れを質む量も, あっ と太く深くしなければならない。だが，それを追 究していくと, 霊長類学自体の枠組みから発する あっと本質的な問題とかかわって来るものと考え られる。結論を言えば, 現在の霊長類学の枠組み を越えて, 医学や人類学を含めた広い視野からの 学問的交流・組織化が要求されていると考えなけ ればならなくなるのだ。そして，医学およびその 関連分野で行われているさまざまな研究も, 進化 という時間軸を含んだ視点から見直していくこと によって, 新しい展開が出てくる可能性がある。 実験系の霊長類学の裾野を広げょうと考えると, 狭い学問領域にとぞまっていないで, 霊長類を軸 とした新しい総合的な実験科学を構築するという 視点を持つ必要が出てくるのである。そうだとす るならば, 実験系の霊長類学の裾野を広げるとい う課題は,これまでの霊長類学の枠組みを越えた 学問分野の構築という課題にふくまれることにな る。そのような学問状況は, 単なる霊長類学や実 験系の霊長類学というような言い方では表現し得 ない。「霊長類医科学」は, 以上のような学問状況 を背景にできたすのと考えられる。そして，医科 学とは正常をむ異常をも等しく扱う立場を強調し ているのであって, 医学の一部に包摂されるとか 医学研究に奉仕することを意味するあのでは全く ない。

霊長類医科学は現在のところ体系化されていな いどころか, そのような学問が成り立つことさえ 多くの研究者たちには未だ自覚されていない。し かし, 霊長類医科学が本来の学問として存在する だけの意味があるのであれば, 研究者たちが自覚 しょうと自覚しまいと，あるいはそのような学問 を中心に据えた学会があろうとなかろうと, 学問 としての体系化が客観的には可能な筈である。

\section{3. 霊長類学の二つの要素}

さて, 霊長類医科学は潜在的に成立している筈 であるとする視点から整理すると, 本来霊長類学 は二つの要素から構成されていたとも言える。ひ とつは自然霊長類学であり, 他のひとつが霊長類 医科学である。これら二つの要素から得られた知 見の蓄積によって, 霊長類のなんたるかが次第に 明らかになって来たのである。自然霊長類学とは 大雑把に言えば今日ふつうに霊長類学と称されて いる学問であり, 霊長類医科学との対比において のみ自然霊長類学と呼ぶことが適当であると考え られる。しからば霊長類医科学とはいかなる学問 であろうか。実験用霊長類学という言葉があった。 否, 現在でもそのような言葉で説明できる学問分 野があることは否定できない。この実験用霊長類 学は, 実験動物学の一分野である之筆者は理解し ている。そのような意味で説明されるとするなら ば, 霊長類医科学は実験用霊長類学とは大きく異 なるものである。実験用霊長類学はその大本の害 験動物学同様, 主として医学研究や試験に利用さ れる動物に関するもろもろの事柄を研究し, 医学 の発展に役立つことを目的とする学問であるのに 対し, 霊長類医科学は霊長類の本質を明らかにす ることを目的にする学問であり, 他の学問研究に 貢献するのは結果としてそうなるだけのことであ る。霊長類医科学は実験動物学のような動物のユー ザーを前提とした学問ではない。霊長類医科学は 実験用霊長類学と異なり，ヒトあ当然ながらその 対象の中に入れて扱う。すなわち, 霊長類医科学 は実験動物学のごとく主に医学に奉仕するのでは なく, 反対に医学をその中に吸収し位置づける。 思うに, 今日の医学はヒトが霊長類の一員である ことを無視した, あるいは軽視した学問であり, 医学教育に拀いて霊長類について教えているとい う話はついぞ聞いたことがない。霊長類の一員で あるヒトを対象とした学問である筈なのに,これ は奇異なことと言わなければならない。

霊長類医科学はヒトもその対象のひとつとして 扱うだけで，医学への貢献を最終目標にするすの ではない。一方, ヒトの生物学的特性の由来や, ヒトの疾病の由来を霊長類進化, 特にヒト化と関 
連して明らかにすることは, まさに霊長類医科学 の範疇に入るテーマと言える。しかもこのような 研究が進展すれば, 医学的視点から見た霊長類学 や霊長類医科学の意義む明確になって来るであろ うし, 霊長類としてのヒトという視座を欠落した 現在の医学研究や医学教育を改めて行くことにも 結びつくであろう。

\section{4 . 霊長類医科学の中核}

霊長類医科学が霊長類の一員としてヒトをあそ の対象とし, 医学研究の成果を積極的に取り入れ るとしても, 当面ヒト以外の霊長類を研究の対象 としていっそう重視するのは当然のことである。 なぜなら，ヒトと違いその他の霊長類は段違いに その本質が知られていないからである。霊長類医 科学は総合的学問領域であり, 個別学問ではない と述べたが，単なる寄せ集めでは学問は成立しな い。中核が必要なのである。霊長類医科学の中核 とは, 現在のところやはり霊長類を生物の中心に おいてそのものの生物学的特性を解析する研究領 域であり，それを担う研究者である。さらにその 中軸になるのは人工環境下に打けるサル類の生物 学的特性の解析であり, それらは以下の三つの基 本グループに分けられる。

\section{第一グループ : 繁殖および育成}

霊長類医科学を進めるあたってまずもって必要 なことは, 研究対象のサル種を人為的に繁殖させ 育成することである。この点においては実験用霊 長類学と非常に近い。しかし実験用霊長類学にお いては, 繁殖効率, 育成効率が第一義的に重視さ れるのに対し, 霊長類医科学における繁殖・育成 の最大の目的はそのサルの生物学的本質を明らか にすることである。それゆえ野外に存在する野生 のサルと繁殖・育成したサルの対比・検討を常に 意識し,サルの形をした実験用動物の生産だけを 追求するようなことをしない。繁殖・育成および そのための研究や開発は, 地味ではあるが霊長類 医科学の基盤であるから，結局はこのグループの 研究水準が其の他の研究のレベルを規定すること になる。

\section{第ニグループ : 基礎データの蓄積}

ヒトというサル種では, 歴史的にその種に関す る基礎的データが無数に蓄積している。ところが, ヒト以外のサル類ではそのようなデータの蓄積は 未だ不十分であり，ヒトとの比較が完全には行え ない。現行のサルを用いた医学研究や試験は，そ のような裏付けがないまま行われている場合が多 く, 資金と労力の浪費をしている恐机あある。こ のような基礎デー夕は永年にわたるコロニーの維 持などの結果ようやく得られるのであるから，実 験動物のユーザー的感覚で学問的流行を追い, 行 政対応的に目先の利害によらわれるような運営を している大施設, 例えば現在の TPC からは,こ のままではあまりみのりある成果は期待できない。

\section{第三グループ : 新しい展開}

繁殖や育成およびそれらに基づく基礎的データ の蓄積があって, 個々のサル種の特性が次第に明 らかになって行く。サル類は, 霊長類とひとくち に括られているが，実態は極めて多様性に富んだ 生物学的特性を持つ動物集団である。というょり, 霊長類はあまり特殊化せず哺乳類の基本形態を維 持していることによって, 生理的適応のポテンシャ リテイを今なお高く維持している動物群であり, それゆえにこそ必要とあらば思いあよらない形質 を獲得している可能性がある。そのような形質を 明らかにし, 生物としての特性を洗い出して行く ことにこそ霊長類医科学の存在する客観的意義が あるのである。

\section{5. なぜサル類を使うのか真剣に考えるへきだ}

筆者は霊長類医科学の発展を願っているが, 一 方では現在の実験系の研究者による霊長類研究の 在り方に疑問を抱いている。新薬の開発や脳研究 など, 時代や社会が要請する場合は, 実験殺をふ くむサル類の利用は制限なく許されるのであろう か。サル類はヒトに近縁と言いつつ，ヒト（人間） だけが至上の存在であるという根拠はどこにある のか。これまでこのような問題については, 実験 系の霊長類研究者は自らの研究の意義についての 多弁とはうらはらにまとあに答えてはこなかった。 
一方, どのような研究や試験であそれなりの手 順を踏めば，何がしかの知見は得られるであろう。 しかし，なぜサルを用いなければならないのか明 確に説明できないような研究・試験や，つまみ食 い的な研究が少なくないように思えてならない。 ヒトでの研究の後追いやヒトを対象にしてでもで きる研究も多い様に思われる。よくよく考えれば, サルならではの研究や試験のテーマは無数に転がっ ているのではないか。それを見つけることができ ないならば，あえてサルにこだわらず他の対象に 転ずるべきである。サルを使うことの意義につい ては, サルを使う限り全ての研究者が自覚的に明 らかにしていくことが大切である。かくて, 霊長 類医科学の中では, 生命倫理や研究の意味, 野生 霊長類保護などについてむ正面から取り上げて行 くことが期待されるのである。

\section{6. おわりに}

霊長類医科学的研究や試験は無数にあるが, 霊 長類医科学自身はまだ独立した学問体系を持つに 至っていない。その手始めにしなければならない ことは, 個別学問分野に埋没している研究を, 霊 長類というキーワードで拾い出し霊長類学という 視点から見直していくこよである。このような状 況にあかかわらず敢えて新しい学問として霊長類 医科学の樹立を提唱する理由は, 実験系の霊長類 の研究が従来の霊長類学や実験動物学の流れの中 では評価む理解も十分にはされて来なかったとい う経験にも基づいている。しかし，常に実験系な どといった便宜的な呼称で自らを規定するのでは, 新しい展望は開けないと思う。筆者の問題提起が 様々な矛盾や欠点をはらんでいることは指摘され るまですないことである。具体性を欠いているの は力不足のゆえでありお許し願いたい。それらは 置いて, 今後前向きの議論が本論をきっかけに起 こることを期待する。 